\title{
PELATIHAN PEMBUATAN ES KRIM DENGAN FORTIFIKASI PROTEIN HEWANI DI KABUPATEN POHUWATO
}

\section{Training Of Ice Cream Creation With Animal Protein Fortification In Pohuwato District}

\author{
Satria Wati Pade ${ }^{1)}$, Desi Arisanti' ${ }^{2)}$, Nur Fitriyanti Bulotio ${ }^{3)}$ \\ 1,2,3) Dosen Program Studi Teknologi Hasil Pertanian, Politeknik Gorontalo \\ Jl. Muchlis Rahim Desa Panggulo, Kecamatan Botupingge Kabaputaen Bone Bolango, Provinsi Gorontalo \\ E-mail : indonk@poligon.ac.id ${ }^{1)}$
}

\begin{abstract}
ABSTRAK
Pada umumnya masyarakat daerah kabupaten Pohuwato mengkonsumsi ikan tuna hanya dimasak untuk dijadikan lauk makan sehari-hari, sehingga timbul kecenderungan rasa bosan terhadap produk ikan tuna. Saat ini belum ada inovasi bagaimana diversifikasi pengolahan ikan tuna ini menjadi produk pangan yang memiliki cita rasa yang bisa disukai oleh semua kalangan masyarakat, Melihat kondisi tersebut tim pengabdian POLIGON ingin mencoba membuat inovasi pangan es krim berbahan dasar daging ikan tuna. Penambahan daging ikan tuna pada pengolahan es krim ini sebagai bentuk fortifikasi untuk mempertahankan atau meningkatkan kandungan protein hewani pada es krim. Tujuan mengikut sertakan ibu-ibu masyarakat desa pada kegiatan ini adalah untuk menambah wawasan mereka tentang pengolahan daging ikan tuna, membangun jiwa kewirausahaan serta memperkenalkan kampus POLIGON sebagai salah satu kampus yang mempunyai visi dan misi untuk mencetak wirausaha muda di bidangnya. Permasalahan yang disepakati untuk diselesaikan bersama yaitu 1) Bagaimana meningkatkan kemampuan mitra untuk mengolah daging ikan tuna menjadi produk yang disukai, 2) Bagaimana membuat es krim fortifikasi protein hewani yang disukai, 3) Bagaimana membangun sinergitas antara pemerintah daerah Pohuwato dengan POLIGON untuk mengarahkan masyarakatnya agar dapat mengembangkan potensi daerah dalam rangka peningkatan ekonomi masyarakat. Adapun solusi yang ditawarkan pada kegiatan ini yaitu 1) membangun kerjasama dengan pihak pemerintah kabupaten melalui kegiatan pelatihan yang dapat menjadi sarana informasi dan pengembangan keterampilan. 2)Es krim protein hewani bisa menjadi salah satu produk unggulan sehingga dapat membantu perekonomian Ibu-Ibu masyarakat di daerah kabupaten Pohuwato.
\end{abstract}

Kata kunci: ikan tuna, es krim, protein

\section{ABSTRACT}

In general, the people of Pohuwato district consume only tuna cooked to be used as a side dish to eat everyday, resulting in a tendency to feel bored with tuna products. There is currently no innovation on how to diversify the processing of tuna into food products that have a taste that can be liked by all groups of people. Seeing this condition, the POLIGON service team wants to try to innovate ice cream based on tuna meat. The addition of tuna meat to the processing of ice cream as a form of fortification to maintain or increase animal protein content in ice cream. The purpose of involving village community mothers in this activity is to broaden their horizons about tuna meat processing, building an entrepreneurial spirit and introducing the POLIGON campus as one of the campuses with a vision and mission to create young entrepreneurs in their fields. The agreed issues to be solved together are 1) How to improve partners' ability to process tuna meat into a preferred product, 2) How to make animal protein fortification ice cream preferred, 3) How to build synergy between the Pohuwato local government and POLIGON to direct their communities to can develop the potential of the region in the context of improving the people's economy. The solutions offered in this activity are 1) building cooperation with the district government through training activities that can be a means of information and 
skills development. 2) Animal protein ice cream can be one of the superior products so that it can help the economy of the community in Pohuwato district.

Keywords : tuna, ice cream, protein

\section{PENDAHULUAN}

Pohuwato memiliki potensi dibidang perikanan disamping potensi pertaniannya. Kawasan ini dikelilingi oleh Teluk Tomini dengan luas perairan Teluk Tomini adalah kurang lebih $43.100 \mathrm{~km} 2$, dengan panjang garis pantai $438.1 \mathrm{~km}$ sepanjang Teluk Tomini. Salah satu potensi sumberdaya perikanan tangkap dengan jenis hasil tangkapan dominan yaitu ikan tuna. (Dinas Kelautan dan Perikanan Kabupaten Pohuwato, 2013). Ikan tuna merupakan salah satu sumber protein hewani yang digemari oleh berbagai kalangan usia. Ikan jenis ini sangat mudah ditemui di perairan yang berada di wilayah Pohuwato.

Pada umumnya masyarakat daerah ini mengkonsumsi ikan tuna hanya dimasak untuk dijadikan lauk makan sehari-hari, sehingga timbul kecenderungan rasa bosan terhadap produk ikan tuna. Sebagian besar anak anak tidak begitu menyukai ikan. Hal ini dikhawatirkan menjadi bisa menjadi masalah dalam proses pertumbuhannya, karena ikan merupakan salah satu sumber zat protein yang bagi tumbuh kembang anak. Saat ini belum ada inovasi bagaimana diversifikasi pengolahan ikan tuna ini menjadi produk pangan yang memiliki cita rasa yang bisa disukai oleh semua kalangan masyarakat, Melihat kondisi tersebut tim pengabdian POLIGON ingin mencoba membuat inovasi pangan es krim dengan penambahan daging ikan tuna. Penambahan daging ikan tuna pada pengolahan es krim ini sebagai bentuk fortifikasi untuk mempertahankan atau meningkatkan kandungan protein hewani pada es krim. Es krim merupakan produk makanan beku yang berasal dari campuran susu, gula, krim, padatan susu bukan lemak, stabilizer dan diberi tambahan flavor sebelum atau setelah pasteurisasi. Es krim memiliki flavor, rasa yang manis, dan umumnya dikonsumsi dalam kondisi beku.

Pada kegiatan pengabdian ini tim POLIGON akan mengkombinasikan es krim dengan penambahan daging ikan tuna. Dalam pengabdian ini tim POLIGON menargetkan mitra yang akan mengembangkan usaha ini adalah ibu-ibu masyarakat yang berada di wilayah tersebut. Tujuan mengikut sertakan ibu-ibu masyarakat desa pada kegiatan ini adalah untuk menambah wawasan mereka tentang pengolahan daging ikan tuna, membangun jiwa kewirausahaan serta memperkenalkan kampus POLIGON sebagai salah satu kampus yang mempunyai visi dan misi untuk mencetak wirausaha muda di bidangnya. Kendala yang mungkin akan ditemui di lapangan adalah terbatasnya pengetahuan mitra tentang pengolahan bahan pangan, manajemen usaha dan motivasi yang rendah untuk berwirausaha.

Berdasarkan latar belakang tersebut, tim pengabdian POLIGON optimis pengolahan es krim sari dengan fortifikasi daging ikan tuna akan disukai oleh masyarakat di wilayah tersebut dan bisa dijadikan usaha untuk meningkatkan pendapatan masyarakat. Keuntungan jangka panjang yang diharapkan pada kegiatan pengabdian ini adalah terbangunnya kerja sama dengan pemerintah daerah Pohuwato untuk mengajak ibu-ibu masyarakat wilayah tersebut agar dapat menularkan 
pengetahuan tentang POLIGON kepada anak-anak mereka khususnya yang duduk dibangku SMA agar melanjutkan pendidikan tingkat tinggi di POLIGON

\section{METODE PELAKSANAAN KEGIATAN}

Rencana kegiatan pengabdian ini dimulai dengan kesepakatan kerja sama antara tim pengabdi dari POLIGON dengan khalayak sasaran yaitu ibu-ibu masyarakat di Kabupaten Pohuwato. Masalah yang sudah dirumuskan kemudian dikaji oleh tim pengabdian dari POLIGON untuk dicari solusinya. Beberapa solusi yang dibuat tim pengabdian POLIGON kemudian didiskusikan kembali dengan mitra untuk dicari solusi mana yang dapat dilaksanakan bersama.

Solusi yang disepakati antara tim pengabdian dengan mitra adalah, kegiatan ini diarahkan untuk menerapkan teknologi diversifikasi pengolahan ikan tuna dalam pembuatan es krim, pelatihan pengolahan es krim. Teknologi tepat guna yang akan digunakan adalah proses diversifikasi pengolahan daging ikan tuna menjadi es krim dengan menyeimbangkan kandungan gizi antara protein hewani dan nabati. Protein merupakan suatu zat makanan yang amat penting bagi tubuh karena karena zat ini disamping sebagai bahan bakar dalam tubuh juga berfungsi sebagai zat pembangun dan pengatur (Winarno, 2002).

Untuk pelaksanaan program pengabdian ini, tim pengabdi POLIGON melakukan beberapa tahap yaitu :

1. Sosialisasi awal rencana pelaksanaan kegiatan pengabdian kepada masyarakat (PKM) pada ibu-ibu melalui pemerintah desa.

2. Peninjauan tempat untuk kegiatan pelatihan kepada yang berlokasi kantor Desa Buntulia Barat
3. Identifikasi alat-alat yang dibutuhkan pada saat kegiatan pengabdian

4. Mempersiapkan kegiatan pelatihan kepada mitra pengabdian tentang ikan tuna, potensi dan olahnnya.

5. Melaksanakan kegiatan pengabdian dalam penyuluhan dan Praktek langsung.

Penyuluhan dilakukan berupa pemaparan teori teknologi diversifikasi pangan dari daging ikan tuna yang dilanjutkan dengan praktek pengolahan es krim. Demonstrasi praktek langsung di lapangan yang didasari oleh evaluasi awal sebagai landasan untuk menentukan permasalahan dan metode yang tepat yang kemudian akan dilakukan evaluasi untuk melihat keberhasilan pencapaian tujuan.

Harapan setelah kegiatan ini, ibu-ibu masyarakat di Kabupaten Pohuwato memperoleh pengetahuan dan keterampilan dalam mengolah ikan tuna menjadi es krim yang memiliki nilai jual lebih sehingga berpeluang untuk dijadikan sebagai modal berwirausaha bagi masyarakat setempat. Manfaat bagi institusi dari kegiatan pelatihan ini adalah terbentuknya komunikasi ilmiah antara pihak kampus dan masyarakat serta pemerintah Kabupaten Pohuwato. Kegiatan pengabdian ini juga merupakan salah satu sarana promosi bagi Politeknik Gorontalo dengan memperkenalkan dan menginformasikan kepada masyarakat tentang keunggulan kampus baik dari segi tenaga pengajar maupun fasilitas pendukung lainnya

\section{HASIL DAN PEMBAHASAN}

Hasil dari beberapa tahapan pelaksanaan pada kegiatan PKM sebagai berikut:

1. Meningkatnya pengetahuan ibu-ibu rumah tangga mengenai diversifikasi 
olahan ikan tuna. Sebelum kegiatan PkM diadakan, ibu-ibu hanya mengolah ikan tuna untuk dikonsumsi sendiri dan keluarga sebagai lauk sehari-hari dengan cara digoreng, ditumis dan dibuat sup ikan, padahal ikan tuna memiliki potensi untuk dikembangkan menjadi berbagai pangan olahan. Oleh karena itu kegiatan diawali dengan penyuluhan tentang ikan tuna, olahan dan potensinya dalam bentuk presentasi powerpoint. Kelebihan yang dimiliki oleh ibu-ibu adalah sumberdaya alam sekitar berupa ikan tuna yang cukup melimpah. Akan tetapi, komoditas ikan tuna di Pohuwato masih memiliki beberapa kelemahan yaitu minimnya produk turunan hasil ikan tuna. Hasilnya dari kegiatan pelatihan ini adalah para ibu-ibu termotivasi untuk memberikan nilai tambah pada produk ikan tuna yang selama ini hanya diolah sebatas sebagai lauk pauk sehari-hari tanpa ada sentuhan teknologi.



Gambar . Kegiatan Pengabdian

2. Ada beberapa kendala yang dihadapi yakni : kesibukan ibu- ibu sebagai IRT sehingga waktu yang disediakan untuk mengikuti pelatihan terbatas, akan tetapi beberapa ibu-ibu tetap semangat mengikuti kegiatan. Kendala lainnya yaitu proses penyiapan ikan agak memakan waktu sehingga mulai dari proses pembersihan, sampai perebusan, sehingga disiasati sebelum pelaksnaan pelatihan inti berlangsung, ikan tuna dibersihkan kepala, ekor serta bagian yang tidak dapat dimakan kemudian direbus terlebih dahulu dan dismpan dalam lemari pendingin satu hari sebelum pelaksanaan kegiatan. Ikan tuna yang sudah matang kemudian diolah menjadi es krim dengan tambahan bahan lainnya. Ikan tuna memiliki aroma dan rasa yang khas sehingga disarankan kepada ibu-ibu agar mengolah es krim dengan tahapan perebusan sampai $2 \mathrm{x}$ sehingga rasa dan aroma khas ikan bisa diminimalisir. beberapa hari sebelum pelaksanaan pelatihan.

\section{Kesimpulan}

Kesimpulan pada kegiatan pengabdian ini antara lain :

1. Terjalinnya kerjasama dengan pihak Pemerintah Desa melalui kegiatan pelatihan yang dapat menjadi sarana informasi dan pengembangan keterampilan.

2. Peningkatan motivasi untuk mengembangkan potensi desa melalui Ibu-ibu sebagai anggota masyarakat desa dengan sentuhan kreatifitas, meningkatnya pengetahuan dan ketrampilan dalam mengolah ikan tuna menjadi es krim salah satu produk bernilai ekonomis yang disukai semua kalangan usia sehingga dapat membantu perekonomian IbuIbu dan masyarakat sekitar khususnya di daerah kecamatan Duhiadaa Kabupaten Pohuwato. 


\section{DAFTAR PUSTAKA}

Anonim, 2010. Ikan tuna.

http://fishbase.com [Diakses 26

September 2019].

Azhar, R. Y. 2012. Es Krim. http://education.wordpress.com/2012/ 07/04.

Kementerian Kelautan dan Perikanan (KKP). 2018. Ekspor Perikanan Gorontalo Capai 40 Ton https://kkp.go.id/bkipm/artikel/7165ekspor-perikanan-gorontalo-capai-40ton [diakses 21 Agustus 2019].

Winarno. 2002. Kimia Pangan dan Gizi. PT. Gramedia Pustaka Utama. Jakarta. 